\title{
ANALISIS KESTABILAN GLOBAL MODEL PENYEBARAN PENYAKIT MENINGITIS DENGAN MENGGUNAKAN FUNGSI LYAPUNOV
}

\author{
Irsya Afifah, Helmi, Evi Noviani
}

\section{INTISARI}

Model matematika dalam penelitian ini merupakan model penyebaran penyakit meningitis bertipe SCIR. Model tersebut dibentuk dengan membagi seluruh populasi menjadi empat sub-populasi yaitu susceptible $(S)$, carrier $(C)$,infected $(I)$, dan recovery $(R)$ serta diasumsikan terdapat pengaruh vaksinasi dan pengobatan. Model tersebut dapat dianalisis kestabilannya dengan terlebih dahulu menentukan titik kesetimbangan bebas penyakit $\left(E_{0}\right)$, titik kesetimbangan endemik $\left(E_{1}\right)$, dan angka reproduksi dasar $\left(\mathfrak{R}_{0}\right)$. Apabila $\mathfrak{R}_{0} \leq 1$ maka titik kesetimbangan bebas penyakit stabil asimtotik global, dan apabila $\mathfrak{R}_{0}>1$ titik kesetimbangan endemik stabil asimtotik global. Sifat tersebut disebut dengan sifat ambang batas. Analisis kestabilan global pada model dilakukan dengan membuktikan adanya fungsi yang memenuhi kriteria kestabilan Lyapunov dan memenuhi sifat ambang batas. Berdasarkan analisis tersebut diperoleh titik kesetimbangan bebas penyakit dan titik kesetimbangan endemik yang stabil asimtotik global. Adapun grafik penyebaran penyakit yang dipengaruhi oleh vaksinasi dan pengobatan dapat dilihat pada grafik simulasi.

Kata Kunci : meningitis, kestabilan global, fungsi Lyapunov, sifat ambang batas

\section{PENDAHULUAN}

Pemodelan matematika dapat digunakan untuk menganalisa penyebaran penyakit seperti meningitis. Meningitis merupakan peradangan yang terjadi di meninges. Meninges adalah selaput yang melindungi sistem saraf pusat [1]. Meningitis dapat disebabkan oleh bakteri. Adapun bakteribakteri penyebab meningitis diantaranya Haemophilus influenzae, Neisseria meningitidis, dan Streptococcus pneumoniae. Meningitis yang disebabkan oleh bakteri disebut meningitis bakterialis. Penyakit ini merupakan penyakit menular yang mematikan. Oleh karena itu, dilakukan berbagai upaya untuk mengontrol penyebarannya diantaranya vaksinasi dan pengobatan. Penyakit meningitis dapat menular dari individu terinfeksi walaupun individu tersebut belum menampakkan gejala. Oleh karena itu, penyebaran penyakit meningitis dapat dimodelkan dengan menggunakan model bertipe $S C I R$ seperti pada penelitian sebelumnya [1], [2]. Adapun SCIR masing-masing melambangkan subpopulasi susceptible, carrier, infected, dan recovery. Pada pemodelan matematika analisis kestabilan model dapat dilakukan dengan berbagai macam metode, beberapa diantaranya seperti metode routhhurwitz dan metode Lyapunov. Metode Lyapunov dapat digunakan untuk model nonlinear seperti pada penelitian ini. Oleh karena itu, digunakan fungsi Lyapunov untuk menganalisis kestabilan model.

Berdasarkan uraian tersebut, maka tujuan pada penelitian ini adalah mengkaji dan mengembangkan model penyebaran penyakit meningitis dengan pengaruh vaksinasi dan pengobatan. Kemudian dilanjutkan dengan menganalisis kestabilan global menggunakan fungsi Lyapunov, dengan terlebih dahulu menentukan titik kesetimbangan model dan angka reproduksi dasar. Setelah diperoleh tipe kestabilan global dari model, dibuat grafik simulasi untuk menginterpretasikan model.

Penelitian ini dibatasi dengan hanya meneliti penyakit meningitis yang disebabkan oleh bakteri. Total populasi dikelompokkan menjadi empat sub-populasi yaitu susceptible, carrier, infected, dan recovery. Sub-populasi susceptible merupakan sub-populasi yang berisi individu-individu yang rentan tertular penyakit. Sub-populasi carrier merupakan sub-populasi yang berisi individu-individu yang telah tertular penyakit dan dapat menularkan penyakit, namun belum menunjukkan gejala. Sub- 
populasi infected berisi individu-individu yang telah tertular penyakit, mampu menularkan penyakit, dan telah menujukkan gejala. Adapun sub-populasi recovery berisi individu-individu yang telah sembuh dari penyakit, atau yang memiliki imunitas sehingga kebal terhadap penyakit.

Penelitian ini diawali dengan melakukan studi pustaka dan mengembangkan model penyebaran penyakit meningitis yang telah diteliti sebelumnya. Kemudian dilanjutkan dengan menentukan titik kesetimbangan $(E)$ dan angka reproduksi dasar $\left(\mathfrak{R}_{0}\right)$. Setelah diperoleh titik kesetimbangan dan angka reproduksi dasar, dilakukan analisis kestabilan menggunakan fungsi Lyapunov. Adapun kestabilan global dapat dibuktikan dengan memenuhi sifat ambang batas. Sifat tersebut yaitu jika $\mathfrak{R}_{0} \leq 1$, titik kesetimbangan bebas penyakit $\left(E_{0}\right)$ stabil asimtotik global dan jika $\mathfrak{R}_{0}>1$, titik kesetimbangan endemik $\left(E_{1}\right)$ stabil asimtotik global [4]. Setelah diperoleh kriteria kestabilan, dilanjutkan dengan simulasi model penyebaran penyakit meningitis menggunakan parameter-parameter yang diperoleh dari penelitian sebelumnya [1], [2]. Langkah terakhir yaitu memberikan interpretasi model matematika penyebaran penyakit meningitis berdasarkan hasil yang diperoleh dari simulasi numerik.

\section{PEMBENTUKAN MODEL MATEMATIKA PENYEBARAN PENYAKIT MENINGITIS}

Pembentukan model matematika penyebaran penyakit meningitis dilakukan dengan memperhatikan beberapa asumsi berikut:

a. Jumlah individu yang lahir sama dengan jumlah individu yang meninggal.

b. Total populasi $(N)$ merupakan jumlah total dari seluruh individu pada setiap sub-populasi. Jumlah individu pada sub-populasi susceptible, carrier, infected, dan recovery masingmasing dilambangkan dengan $\dot{S}, \dot{C}, \dot{I}$, dan $\dot{R}$. Total populasi dapat dinyatakan dengan $N=\dot{S}+\dot{C}+\dot{I}+\dot{R}$ dan dianggap konstan.

c. Individu susceptible yang divaksinasi akan bertahan imunitasnya maksimal selama 5 tahun dan masuk kedalam sub-populasi recovery.

d. Vaksin meningitis dapat diberikan ke semua golongan umur dan jenis kelamin.

e. Individu carrier dapat sembuh secara alami, serta dapat pula sembuh melalui pengobatan.

Berdasarkan asumsi di atas, maka dibentuklah model penyebaran penyakit meningitis sebagai berikut:

1. Sub-populasi rentan (susceptible)

Bertambahnya individu pada sub-populasi susceptible dikarenakan adanya individu baru yang dilambangkan dengan $\Lambda$. Individu baru yang tidak menjalani vaksinasi akan masuk ke dalam subpopulasi susceptible, dilambangkan dengan $\Lambda\left(1-u_{1} \sigma\right)$. Jumlah anggota sub-populasi susceptible juga akan bertambah dengan adanya $\theta \dot{R}$ yang merupakan jumlah individu yang telah pulih dari penyakit (recovery) yang kembali menjadi individu rentan dikarenakan hilangnya imunitas. Jumlah anggota sub-populasi susceptible berkurang dengan adanya kontak antara individu rentan dan individu terinfeksi, dilambangkan dengan $\frac{\beta \dot{S}(\dot{C}+\dot{I})}{N}$. Kemudian berkurang kembali dengan adanya kematian alami dan vaksinasi pada individu rentan, dilambangkan dengan $\left(\mu+u_{1} \sigma\right) \dot{S}$. Perubahan dinamis jumlah individu pada sub-populasi susceptible dapat dituliskan sebagai berikut:

$$
\frac{d \dot{S}}{d t}=\Lambda\left(1-u_{1} \sigma\right)-\frac{\beta \dot{S}(\dot{C}+\dot{I})}{N}-\left(\mu+u_{1} \sigma\right) \dot{S}+\theta \dot{R}
$$

2. Sub-populasi terinfeksi tanpa gejala (carrier)

Jumlah individu pada sub-populasi carrier akan bertambah dengan adanya individu rentan yang berubah menjadi individu terinfeksi $\left(\frac{\beta \dot{S}(\dot{C}+\dot{I})}{N}\right)$. Kemudian akan berkurang dengan adanya perkembangan infeksi menjadi infeksi bergejala $(\alpha \dot{C})$, kesembuhan alami $(\omega \dot{C})$, kesembuhan akibat pengobatan $\left(u_{2} \gamma \dot{C}\right)$, dan kematian alami $(\mu \dot{C})$. Perubahan dinamis jumlah individu pada sub-populasi carrier dapat dituliskan sebagai berikut: 


\section{Sub-populasi terinfeksi (infected)}

$$
\frac{d \dot{C}}{d t}=\frac{\beta \dot{S}(\dot{C}+\dot{I})}{N}-\left(\alpha+\omega+\mu+u_{2} \gamma\right) \dot{C}
$$

Pada sub-populasi infected bertambahnya jumlah individu disebabkan karena adanya perubahan infeksi menjadi infeksi bergejala, dilambangkan dengan $\alpha \dot{C}$. Kemudian berkurang dengan adanya kesembuhan $\left(u_{2} \gamma \dot{I}\right)$, kematian akibat penyakit $(\delta \dot{I})$, dan kematian alami $(\mu \dot{I})$. Perubahan dinamis jumlah individu pada sub-populasi infected dapat dituliskan sebagai berikut:

4. Sub-populasi sembuh/kebal (recovery)

$$
\frac{d \dot{I}}{d t}=\alpha \dot{C}-\left(\delta+\mu+u_{2} \gamma\right) \dot{I}
$$

Pada sub-populasi recovery, jumlah anggotanya akan bertambah dengan adanya individu terinfeksi yang sembuh dari penyakit $\left(\left(\omega+u_{2} \gamma\right) \dot{C}\right)+\left(u_{2} \gamma \dot{I}\right)$, serta adanya individu yang divaksinasi $\left(\Lambda u_{1} \sigma\right)+\left(u_{1} \sigma \dot{S}\right)$. Jumlah anggota sub-populasi recovery akan berkurang karena adanya individu yang kehilangan imunitas $(\theta \dot{R})$, serta adanya kematian alami $(\mu \dot{R})$. Perubahan dinamis jumlah individu pada sub-populasi recovery dapat dituliskan sebagai berikut:

$$
\frac{d \dot{R}}{d t}=\Lambda u_{1} \sigma+u_{2} \gamma \dot{I}+\left(\omega+u_{2} \gamma\right) \dot{C}+u_{1} \sigma \dot{S}-(\mu+\theta) \dot{R}
$$

Diagram alir model penyebaran penyakit meningitis dapat dilihat dari Gambar 3.1 berikut.

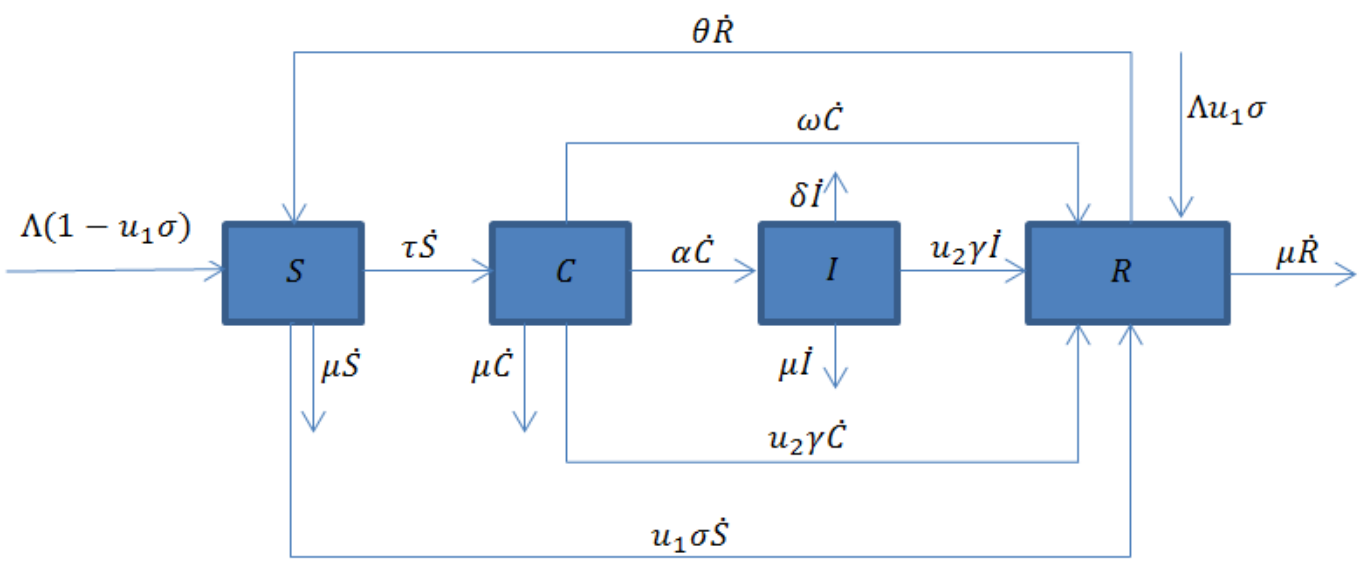

Gambar 1 Diagram alir penyebaran penyakit meningitis

dengan $\tau=\frac{\beta(\dot{C}+\dot{I})}{N}$ dan total populasi $N=\dot{S}+\dot{C}+\dot{I}+\dot{R}$.

Dengan demikian, diperoleh sistem persamaan diferensial sebagai berikut:

Perubahan total populasi yaitu

$$
\left.\begin{array}{l}
\frac{d \dot{S}}{d t}=\Lambda\left(1-u_{1} \sigma\right)-\frac{\beta \dot{S}(\dot{C}+\dot{I})}{\dot{N}}-\left(\mu+u_{1} \sigma\right) \dot{S}+\theta \dot{R} \\
\frac{d \dot{C}}{d t}=\frac{\beta \dot{S}(\dot{C}+\dot{I})}{\dot{N}}-\left(\alpha+\omega+\mu+u_{2} \gamma\right) \dot{C} \\
\frac{d \dot{I}}{d t}=\alpha \dot{C}-\left(\delta+\mu+u_{2} \gamma\right) \dot{I} \\
\frac{d \dot{R}}{d t}=\Lambda u_{1} \sigma+u_{2} \gamma \dot{I}+\left(\omega+u_{2} \gamma\right) \dot{C}+u_{1} \sigma \dot{S}-(\mu+\theta) \dot{R}
\end{array}\right\}
$$

$$
\frac{d N}{d t}=\frac{d \dot{S}}{d t}+\frac{d \dot{C}}{d t}+\frac{d \dot{I}}{d t}+\frac{d \dot{R}}{d t}=\Lambda-\mu N-\delta \dot{I}
$$

Diasumsikan rekruitmen bernilai sama dengan jumlah angka kematian, baik itu kematian alami atau kematian akibat penyakit sehingga $\Lambda=\mu N+\delta \dot{I}$, sehingga diperoleh $\frac{d N}{d t}=0$ [3]. Untuk memudahkan 
perhitungan, model diatas diskalakan dengan total populasi $(N)$, sehingga menjadi $1=S+C+I+$ $R$. Adapun $S, C, I$, dan $R$ masing-masing melambangkan jumlah sub-populasi susceptible, carrier, infected, dan recovery, serta dapat dinyatakan dengan $S=\frac{\dot{S}}{N}, C=\frac{\dot{C}}{N}, I=\frac{\dot{I}}{N}, R=\frac{\dot{R}}{N}$. Misalkan $\dot{X}=$ $\dot{S}, \dot{C}, \dot{I}, \dot{R}$ dan $X=S, C, I, R$, dengan kata lain $X=\frac{\dot{X}}{N}$. Dengan demikian $\frac{d X}{d t}=\frac{1}{N}\left(\frac{d \dot{X}}{d t}\right)$, sehingga persamaan (1) dapat ditulis sebagai berikut:

$$
\left.\begin{array}{l}
\frac{d S}{d t}=\Lambda\left(1-u_{1} \sigma\right)-\beta S(C+I)-\left(\mu+u_{1} \sigma\right) S+\theta R \\
\frac{d C}{d t}=\beta S(C+I)-\left(\alpha+\omega+\mu+u_{2} \gamma\right) C \\
\frac{d I}{d t}=\alpha C-\left(\delta+\mu+u_{2} \gamma\right) I \\
\frac{d R}{d t}=\Lambda u_{1} \sigma+u_{2} \gamma I+\left(\omega+u_{2} \gamma\right) C+u_{1} \sigma S-(\mu+\theta) R
\end{array}\right\}
$$

Dengan $S(0)>0, C(0) \geq 0, I(0) \geq 0, R(0) \geq 0$.

\section{ANALISIS KESTABILAN GLOBAL PADA TITIK KESETIMBANGAN}

Analisis kestabilan pada titik kesetimbangan memerlukan angka reproduksi dasar $\left(\mathfrak{R}_{0}\right)$. Angka reproduksi dasar merupakan angka rata-rata banyaknya infeksi yang dilakukan oleh individu terinfeksi. Titik kesetimbangan dari sistem pada Persamaan (2) diperoleh ketika $\frac{d s}{d t}=0, \frac{d C}{d t}=0$, $\frac{d I}{d t}=0$, dan $\frac{d R}{d t}=0$. Sehingga diperoleh titik kesetimbangan bebas penyakit $E_{0}=\left(S_{0}, C_{0}, I_{0}, R_{0}\right)=$ $\left(\frac{\mu+\theta-\mu u_{1} \sigma}{\mu+\theta+u_{1} \sigma}, 0,0, \frac{u_{1} \sigma(\mu+1)}{\mu+\theta+u_{1} \sigma}\right)$, angka reproduksi dasar $\mathfrak{R}_{0}=\frac{\beta\left(\mu+\theta-\mu u_{1} \sigma\right)\left(\alpha+\delta+\mu+u_{2} \gamma\right)}{\left(\alpha+\omega+\mu+u_{2} \gamma\right)\left(\delta+\mu+u_{2} \gamma\right)\left(u_{1} \sigma+\mu+\theta\right)}$, dan titik kesetimbangan endemik $E_{1}=\left(S_{1}, C_{1}, I_{1}, R_{1}\right)$ sebagai berikut:

$$
\begin{aligned}
& S_{1}=\frac{\left(\mu+\theta-\mu u_{1} \sigma\right)}{\mathfrak{R}_{0}\left(u_{1} \sigma+\mu+\theta\right)} \\
& C_{1}=\frac{\left(\Re_{0}-1\right)\left(u_{1} \sigma+\mu+\theta\right)\left(\alpha+\omega+\mu+u_{2} \gamma\right)\left(\delta+\mu+u_{2} \gamma\right)^{2}}{\left(-\beta\left(\alpha+\delta+\mu+u_{2} \gamma\right)\left(\alpha\left(\delta u_{1} \sigma+\theta+\mu+u_{2} \gamma\right)+\left(\mu+\theta+\omega+u_{2} \gamma\right)\left(\delta+\mu+u_{2} \gamma\right)\right)\right)} \\
& I_{1}=\frac{\alpha\left(\Re_{0}-1\right)\left(u_{1} \sigma+\mu+\theta\right)\left(\alpha+\omega+\mu+u_{2} \gamma\right)\left(\delta+\mu+u_{2} \gamma\right)}{\left(-\beta\left(\alpha+\delta+\mu+u_{2} \gamma\right)\left(\alpha\left(\delta u_{1} \sigma+\theta+\mu+u_{2} \gamma\right)+\left(\mu+\theta+\omega+u_{2} \gamma\right)\left(\delta+\mu+u_{2} \gamma\right)\right)\right)}
\end{aligned}
$$

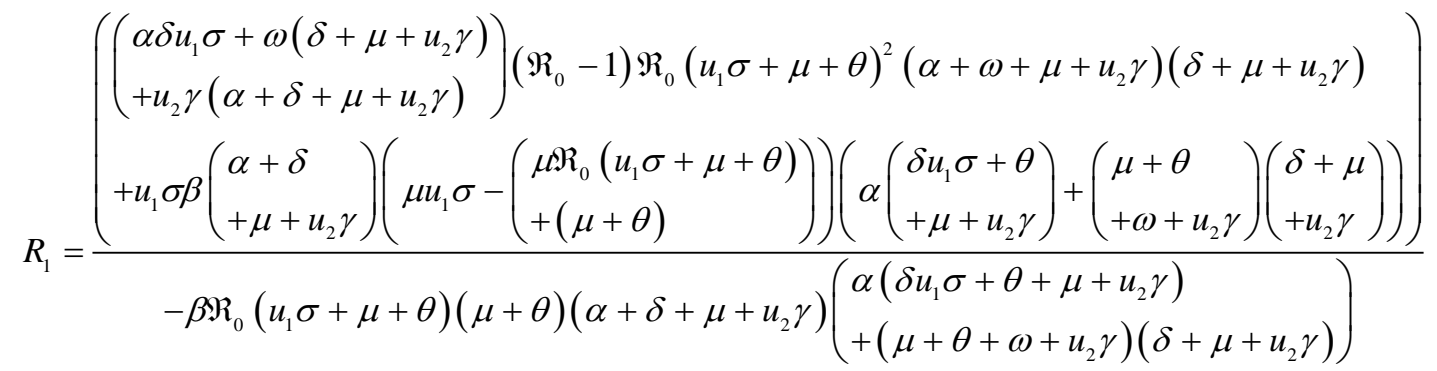

Misalkan terdapat sebuah fungsi $V: U \subset \mathbb{R}^{n} \rightarrow \mathbb{R}$, fungsi $V$ disebut fungsi Lyapunov jika memenuhi Definisi 1.

Definisi 1 [5] Misalkan $x^{*}$ merupakan titik kesetimbangan dari sebuah sistem dinamik. Fungsi Lyapunov $(V)$ yang didefinisikan pada daerah $U$ yang mengandung $x^{*}$ di dalamnya, ialah fungsi yang memenuhi tiga pernyataan berikut:

1) $V$ kontinu dan memiliki turunan pertama yang kontinu.

2) $V(x)$ memiliki minimum unik pada $x^{*}$ berkaitan dengan semua titik di $U$ 
3) Turunan dari fungsi $V(x)$ yaitu $\frac{d V(x)}{d x}$ memenuhi $\frac{d V(x)}{d x} \leq 0$ untuk semua $x$ di $U$.

Teorema 2 [6] Misalkan terdapat sebuah sistem persamaan diferensial $\boldsymbol{x}^{\prime}=\left[\frac{d x_{1}}{d t}, \ldots, \frac{d x_{n}}{d t}\right]=\boldsymbol{f}(\boldsymbol{x})$, dengan titik kesetimbangannya yang dilambangkan dengan $x^{*}$. dan misalkan fungsi $V$ pada $x$ yang bersifat:

1. $V(x) \geq 0$ untuk $x \in U$ dan $V(x)=0$ jika dan hanya jika $x=0$,

2. $V^{\prime}(x) \leq 0$ untuk $x \in U$ dan $V^{\prime}(x)=0$ jika dan hanya jika $x=0$.

maka titik kesetimbangan $x^{*}=0$ stabil asimtotik lokal.

Pada penelitian sebelumnya [2], telah didefinisikan fungsi Lyapunov untuk model SCIR pada titik kesetimbangan bebas penyakit dengan konstanta positif $k_{1}$ dan $k_{2}$ sebagai berikut:

$$
V(S, C, I, R)=\left(S-S_{0}-S_{0} \ln \left(\frac{S}{S_{0}}\right)\right)+k_{1} C+k_{2} I+\left(R-R_{0}-R_{0} \ln \left(\frac{R}{R_{0}}\right)\right)
$$

Berdasarkan Teorema 2, diselidiki apakah $V(S, C, I, R)=0$ untuk $(S, C, I, R)=\left(S_{0}, C_{0}, I_{0}, R_{0}\right)$ dan $V(S, C, I, R) \geq 0$ untuk $(S, C, I, R) \neq\left(S_{0}, C_{0}, I_{0}, R_{0}\right)$ sebagai berikut:

$\operatorname{Untuk}(S, C, I, R)=\left(S_{0}, C_{0}, I_{0}, R_{0}\right)$,

$$
\begin{aligned}
V(S, C, I, R) & =\left(S-S_{0}-S_{0} \ln \frac{S}{S_{0}}\right)+k_{1} C+k_{2} I+\left(R-R_{0}-R_{0} \ln \frac{R}{R_{0}}\right) \\
& =S_{0}\left(\frac{S}{S_{0}}-1-\ln \frac{S}{S_{0}}\right)+R_{0}\left(\frac{R}{R_{0}}-1-\ln \frac{R}{R_{0}}\right) \\
& =\left(\frac{\mu+\theta-\mu u_{1} \sigma}{\mu+\theta+u_{1} \sigma}\right)(1-1-\ln 1)+\left(\frac{u_{1} \sigma(\mu+1)}{\mu+\theta+u_{1} \sigma}\right)(1-1-\ln 1) \\
& =0
\end{aligned}
$$

Untuk $(S, C, I, R) \neq\left(S_{0}, C_{0}, I_{0}, R_{0}\right), \frac{S}{S_{0}} \neq 1$ sehingga

Dengan demikian,

$$
\frac{S}{S_{0}}-1-S_{0} \ln \left(\frac{S}{S_{0}}\right) \neq 0, \text { dan } \frac{R}{R_{0}}-1-R_{0} \ln \left(\frac{R}{R_{0}}\right) \neq 0
$$

$$
\begin{aligned}
V(S, C, I, R) & =\left(S-S_{0}-S_{0} \ln \frac{S}{S_{0}}\right)+k_{1} C+k_{2} I+\left(R-R_{0}-R_{0} \ln \frac{R}{R_{0}}\right) \\
& =S_{0}\left(\frac{S}{S_{0}}-1-\ln \frac{S}{S_{0}}\right)+k_{1} C+k_{2} I+R_{0}\left(\frac{R}{R_{0}}-1-\ln \frac{R}{R_{0}}\right)
\end{aligned}
$$

Terlihat bahwa $V(S, C, I, R)$ akan bernilai positif jika $S_{0}\left(\frac{S}{S_{0}}-1-\ln \frac{S}{S_{0}}\right)>0$ dan $R_{0}\left(\frac{R}{R_{0}}-1-\right.$ $\left.\ln \frac{R}{R_{0}}\right)>0$. Misalkan $\frac{S}{S_{0}}, \frac{R}{R_{0}}=x$, kemudian misalkan terdapat sebuah fungsi $g(x)=x-1-\ln x$, fungsi $g(x)$ akan mencapai minimum global pada $x=1$ dan $g(1)=0$. Oleh karena itu, $g(x)>0$ untuk semua $x>0$ dan $x \neq 1$. Maka $V(S, C, I, R)$ bernilai positif jika $\frac{S}{S_{0}}, \frac{R}{R_{0}}>0$ dan $\frac{S}{S_{0}}, \frac{R}{R_{0}} \neq 1$.

Adapun turunan dari fungsi $V$ pada Persamaan (4) adalah sebagai berikut:

$$
\begin{aligned}
\frac{\partial V(S, C, I, R)}{\partial t} & =\frac{d V}{d S} \cdot \frac{d S}{d t}+\frac{d V}{d C} \cdot \frac{d C}{d t}+\frac{d V}{d I} \cdot \frac{d I}{d t}+\frac{d V}{d R} \cdot \frac{d R}{d t} \\
& =\left(1-\frac{S_{0}}{S}\right) \cdot \frac{d S}{d t}+k_{1} \cdot \frac{d C}{d t}+k_{2} \cdot \frac{d I}{d t}+\left(1-\frac{R_{0}}{R}\right) \cdot \frac{d R}{d t} .
\end{aligned}
$$

Substitusikan $\frac{d S}{d t}, \frac{d C}{d t}, \frac{d I}{d t}$, dan $\frac{d R}{d t}$ dari Persamaan (2) ke Persamaan (5) diperoleh 


$$
\frac{\partial V(S, C, I, R)}{\partial t}=\left(\begin{array}{c}
\left(1-\frac{S_{0}}{S}\right)\left((\mu+\delta I)\left(1-u_{1} \sigma\right)-\beta S(C+I)-\left(\mu+u_{1} \sigma\right) S+\theta R\right) \\
+k_{1}\left(\beta S(C+I)-\left(\alpha+\omega+\mu+u_{2} \gamma\right) C\right)+k_{2}\left(\alpha C-\left(\delta+\mu+u_{2} \gamma\right) I\right) \\
+\left(1-\frac{R_{0}}{R}\right)\left(u_{2} \gamma I+\left(\omega+u_{2} \gamma\right) C+u_{1} \sigma S+(\mu+\delta I) u_{1} \sigma-(\theta+\mu) R\right)
\end{array}\right)
$$

Berdasarkan Teorema 2, akan diselidiki apakah $\frac{\partial V(S, C, I, R)}{\partial t}=0$ untuk $(S, C, I, R)=\left(S_{0}, C_{0}, I_{0}, R_{0}\right)$ dan $\frac{\partial V(S, C, I, R)}{\partial t} \leq 0$ untuk $(S, C, I, R) \neq\left(S_{0}, C_{0}, I_{0}, R_{0}\right)$ sebagai berikut:

$\operatorname{Untuk}(S, C, I, R)=\left(S_{0}, C_{0}, I_{0}, R_{0}\right)$,

$$
\begin{aligned}
\frac{\partial V(S, C, I, R)}{\partial t}= & \left(\begin{array}{c}
\left(1-\frac{S_{0}}{S}\right)\left((\mu+\delta I)\left(1-u_{1} \sigma\right)-\beta S(C+I)-\left(\mu+u_{1} \sigma\right) S+\theta R\right) \\
+k_{1}\left(\beta S(C+I)-\left(\alpha+\omega+\mu+u_{2} \gamma\right) C\right)+k_{2}\left(\alpha C-\left(\delta+\mu+u_{2} \gamma\right) I\right) \\
+\left(1-\frac{R_{0}}{R}\right)\left(u_{2} \gamma I+\left(\omega+u_{2} \gamma\right) C+u_{1} \sigma S+(\mu+\delta I) u_{1} \sigma-(\theta+\mu) R\right)
\end{array}\right) \\
= & 0
\end{aligned}
$$

Untuk $(S, C, I, R) \neq\left(S_{0}, C_{0}, I_{0}, R_{0}\right)$, ketika $S \leq S_{0}$, dan $R \leq R_{0}$, maka

$$
\begin{aligned}
\frac{\partial V(S, C, I, R)}{\partial t} \leq\left[k_{1}\left(\begin{array}{l}
\frac{\beta\left(\mu+\theta-\mu u_{1} \sigma\right)}{\left(u_{1} \sigma+\mu+\theta\right)} C+\frac{\beta\left(\mu+\theta-\mu u_{1} \sigma\right)}{\left(u_{1} \sigma+\mu+\theta\right)} I \\
-\left(\alpha+\omega+\mu+u_{2} \gamma\right) C
\end{array}\right)+k_{2}\left(\alpha C-\left(\delta+\mu+u_{2} \gamma\right) I\right)\right] \\
=\left[\begin{array}{l}
\left(\begin{array}{l}
k_{1} \frac{\beta\left(\mu+\theta-\mu u_{1} \sigma\right)}{\left(u_{1} \sigma+\mu+\theta\right)}-k_{1}\left(\alpha+\omega+\mu+u_{2} \gamma\right) \\
+k_{2} \alpha
\end{array}\right) C \\
+\left(k_{1} \frac{\beta\left(\mu+\theta-\mu u_{1} \sigma\right)}{\left(u_{1} \sigma+\mu+\theta\right)}-k_{2}\left(\delta+\mu+u_{2} \gamma\right)\right) I
\end{array}\right]
\end{aligned}
$$

Misalkan

$$
\begin{gathered}
\left(k_{1} \frac{\beta\left(\mu+\theta-\mu u_{1} \sigma\right)}{\left(u_{1} \sigma+\mu+\theta\right)}-k_{2}\left(\delta+\mu+u_{2} \gamma\right)\right)=0 \\
k_{1} \frac{\beta\left(\mu+\theta-\mu u_{1} \sigma\right)}{\left(u_{1} \sigma+\mu+\theta\right)}=k_{2}\left(\delta+\mu+u_{2} \gamma\right)
\end{gathered}
$$

Dipilih $k_{1}=\left(\delta+\mu+u_{2} \gamma\right)$ dan $k_{2}=\frac{\beta\left(\mu+\theta-\mu u_{1} \sigma\right)}{\left(u_{1} \sigma+\mu+\theta\right)}$, sehingga

$$
\begin{aligned}
\frac{\partial V(S, C, I, R)}{\partial t} \leq\left[\left(\frac{\beta\left(\alpha+\delta+\mu+u_{2} \gamma\right)\left(\mu+\theta-\mu u_{1} \sigma\right)}{u_{1} \sigma+\mu+\theta}-\left(\delta+\mu+u_{2} \gamma\right)\left(\alpha+\omega+\mu+u_{2} \gamma\right)\right) C\right] \\
=\left[\left(\delta+\mu+u_{2} \gamma\right)\left(\alpha+\omega+\mu+u_{2} \gamma\right)\left(\Re_{0}-1\right) C\right]
\end{aligned}
$$

diperoleh $\frac{\partial V(S, C, I, R)}{\partial t} \leq 0$ jika $\Re_{0} \leq 1$

Oleh karena model memenuhi sifat ambang batas, maka dapat dikatakan bahwa model penyebaran penyakit meningitis pada titik kesetimbangan bebas penyakit stabil asimtotik global.

Pada titik kesetimbangan endemik digunakan fungsi Lyapunov yang diperleh dari penelitian sebelumnya [2] sebagai berikut:

$$
V(S, C, I, R)=\frac{1}{2}\left[\left(S-S_{1}\right)+\left(C-C_{1}\right)+\left(I-I_{1}\right)+\left(R-R_{1}\right)\right]^{2}
$$


Berdasarkan Teorema 2, akan diselidiki apakah $V(S, C, I, R)=0$ untuk $(S, C, I, R)=\left(S_{0}, C_{0}, I_{0}, R_{0}\right)$ dan $V(S, C, I, R) \geq 0$ untuk $(S, C, I, R) \neq\left(S_{0}, C_{0}, I_{0}, R_{0}\right)$ sebagai berikut:

$\operatorname{Untuk}(S, C, I, R)=\left(S_{1}, C_{1}, I_{1}, R_{1}\right)$,

$$
\begin{aligned}
V(S, C, I, R) & =\frac{1}{2}\left[\left(S-S_{1}\right)+\left(C-C_{1}\right)+\left(I-I_{1}\right)+\left(R-R_{1}\right)\right]^{2} \\
& =\frac{1}{2}[(0)+(0)+(0)+(0)]^{2} \\
& =0
\end{aligned}
$$

Untuk $(S, C, I, R) \neq\left(S_{1}, C_{1}, I_{1}, R_{1}\right)$,

$$
\begin{aligned}
V(S, C, I, R) & =\frac{1}{2}\left[\left(S-S_{1}\right)+\left(C-C_{1}\right)+\left(I-I_{1}\right)+\left(R-R_{1}\right)\right]^{2} \\
& >0
\end{aligned}
$$

diperoleh $V(S, C, I, R)$ bernilai positif.

Adapun turunan dari fungsi $V$ pada Persamaan (6) ialah sebagai berikut

$$
\frac{\partial V}{\partial t}(\mathrm{~S}, C, I, R)=\left[\begin{array}{l}
\left(S-S_{1}\right)+\left(C-C_{1}\right) \\
+\left(I-I_{1}\right)+\left(R-R_{1}\right)
\end{array}\right] \frac{d(S+C+I+R)}{d t}
$$

Berdasarkan Teorema 2, akan diselidiki apakah $\frac{\partial V(S, C, I, R)}{\partial t}=0$ untuk $(S, C, I, R)=\left(S_{1}, C_{1}, I_{1}, R_{1}\right)$ dan $\frac{\partial V(S, C, I, R)}{\partial t} \leq 0$ untuk $(S, C, I, R) \neq\left(S_{1}, C_{1}, I_{1}, R_{1}\right)$ sebagai berikut:

$\operatorname{Untuk}(S, C, I, R)=\left(S_{1}, C_{1}, I_{1}, R_{1}\right)$,

$$
\begin{aligned}
\frac{\partial V}{\partial t}(\mathrm{~S}, C, I, R) & =\left[\begin{array}{l}
\left(S-S_{1}\right)+\left(C-C_{1}\right) \\
+\left(I-I_{1}\right)+\left(R-R_{1}\right)
\end{array}\right] \frac{d(S+C+I+R)}{d t} \\
& =0
\end{aligned}
$$

Untuk $(S, C, I, R) \neq\left(S_{1}, C_{1}, I_{1}, R_{1}\right)$, telah diketahui sebelumnya bahwa $N=S+C+I+R$ dan $\frac{d N}{d t}=\Lambda-\mu N-\delta I$. Dengan demikian maka

$$
\frac{\partial V}{\partial t}=\left[\begin{array}{c}
\left(S-S_{1}\right)+\left(C-C_{1}\right) \\
+\left(I-I_{1}\right)+\left(I-I_{1}\right)
\end{array}\right][\Lambda-\mu(S+C+I+R)-\delta I]
$$

Misalkan, $\Lambda=\mu\left(S_{1}, C_{1}, I_{1}, R_{1}\right)+\delta I_{1}$, maka

$$
\begin{aligned}
& \frac{\partial V}{\partial t}= {\left.\left[\left(S-S_{1}\right)+\left(C-C_{1}\right)+\left(I-I_{1}\right)+\left(R-R_{1}\right)\right]\left[\mu\left(S_{1}+C_{1}+I_{1}+R_{1}\right)+\delta \mathrm{I}_{1}-\mu(S+C+I+R)-\delta\right]\right] } \\
&= {\left[\left(S-S_{1}\right)+\left(C-C_{1}\right)+\left(I-I_{1}\right)+\left(R-R_{1}\right)\right]\left[\begin{array}{l}
-\mu\left(S-S_{1}\right)-\mu\left(C-C_{1}\right)-\mu\left(I-I_{1}\right) \\
-\mu\left(R-R_{1}\right)-\delta\left(I-I_{1}\right)
\end{array}\right] } \\
& \frac{\partial V}{\partial t}=-\left(\begin{array}{l}
\mu\left(S-S_{1}\right)^{2}+2 \mu\left(S-S_{1}\right)\left(C-C_{1}\right)+\mu\left(C-C_{1}\right)^{2}+(\mu+\delta)\left(I-I_{1}\right)^{2}+\mu\left(R-R_{1}\right)^{2} \\
+(2 \mu+\delta)\left(I-I_{1}\right)\left(\left(S-S_{1}\right)+\left(C-C_{1}\right)+\left(R-R_{1}\right)\right)+\left[\mu\left(S-S_{1}\right)\left(R-R_{1}\right)+\mu\left(C-C_{1}\right)\left(R-R_{1}\right)\right]
\end{array}\right)
\end{aligned}
$$

Dengan mensubstitusikan nilai $E_{1}$, diperoleh

$$
\begin{aligned}
& S-S_{1}=S-\left(\frac{-\left(\mu u_{1} \sigma-(\mu+\theta)\right)}{\mathfrak{R}_{0}\left(u_{1} \sigma+\mu+\theta\right)}\right)>0 \\
& C-C_{1}=C-\left(\frac{\left(\mathfrak{R}_{0}-1\right)\left(u_{1} \sigma+\mu+\theta\right)\left(\alpha+\omega+\mu+u_{2} \gamma\right)\left(\delta+\mu+u_{2} \gamma\right)^{2}}{\left(-\beta\left(\alpha+\delta+\mu+u_{2} \gamma\right)\left(\alpha\left(\delta u_{1} \sigma+\theta+\mu+u_{2} \gamma\right)+\left(\mu+\theta+\omega+u_{2} \gamma\right)\left(\delta+\mu+u_{2} \gamma\right)\right)\right)}\right)>0 \\
& I-I_{1}=I-\left(\frac{\alpha\left(\mathfrak{R}_{0}-1\right)\left(u_{1} \sigma+\mu+\theta\right)\left(\alpha+\omega+\mu+u_{2} \gamma\right)\left(\delta+\mu+u_{2} \gamma\right)}{\left(-\beta\left(\alpha+\delta+\mu+u_{2} \gamma\right)\left(\alpha\left(\delta u_{1} \sigma+\theta+\mu+u_{2} \gamma\right)+\left(\mu+\theta+\omega+u_{2} \gamma\right)\left(\delta+\mu+u_{2} \gamma\right)\right)\right)}\right)>0
\end{aligned}
$$




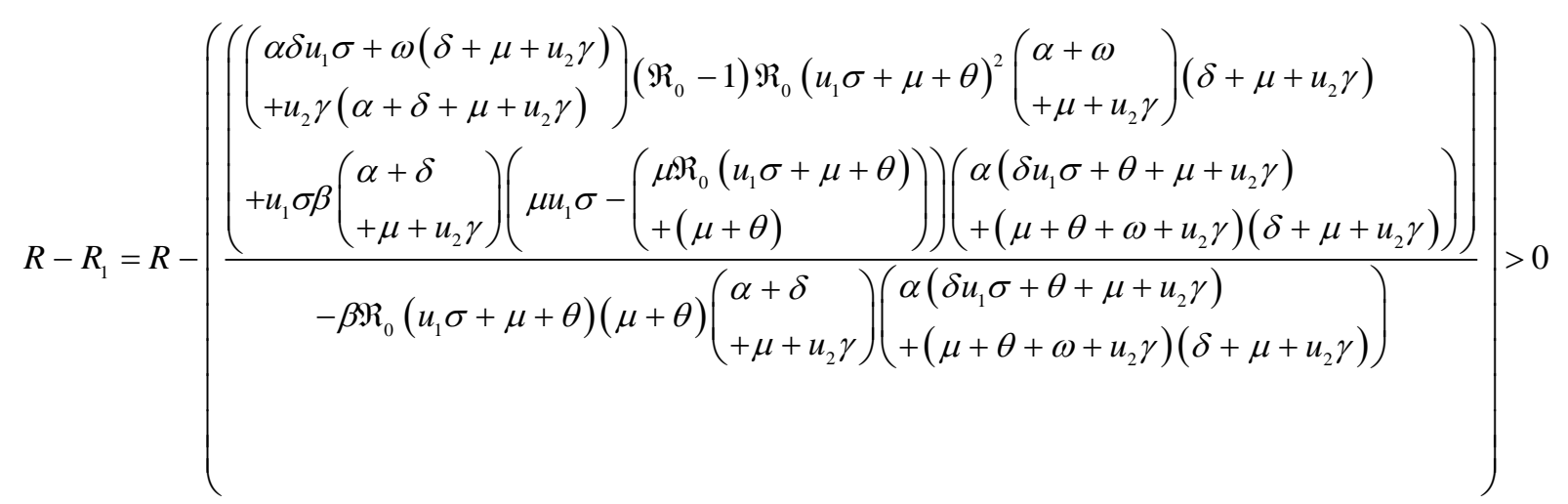

jika $\mu u_{1} \sigma>\mu \Re_{0}\left(\mu+\theta+u_{1} \sigma\right)+(\mu+\theta), \Re_{0}>1$. Oleh karena itu, maka $\frac{\partial V}{\partial t}$ bernilai negatif.

Oleh karena model memenuhi sifat ambang batas, maka dapat dikatakan bahwa model penyebaran penyakit meningitis pada titik kesetimbangan endemik stabil asimtotik global.

\section{SIMULASI MODEL PENYEBARAN PENYAKIT MENINGITIS}

Simulasi dilakukan untuk mendapatkan gambaran mengenai penyebaran penyakit meningitis. Perlu didefiniskan beberapa parameter untuk dapat melakukan simulasi. Parameter $u_{1} \sigma$ dan $u_{2} \gamma$ masingmasing didefinisikan sebagai persentase vaksin dan pengobatan, yang mana akan divariasikan untuk melihat bagaimana pengaruhnya terhadap model.

Angka kematian alami $(\mu)$ bernilai 0.01 , sedangkan angka kematian akibat penyakit $(\delta)$ bernilai 0.1 [1]. Kemudian diasumsikan pula laju kontak efektif $(\beta)$ bernilai 0.88 , laju perkembangan infeksi menjadi infeksi bergejala $(\alpha)$ bernilai 0.2 , laju hilangnya imunitas $(\theta)$ bernilai 0.0839 , angka kesembuhan alami $(\omega)$ bernilai 0.2 , angka efektifitas vaksin $(\sigma)$ bernilai 0.85 , serta angka efektifitas pengobatan $(\gamma)$ bernilai 0.9 [2]. Adapun nilai awal yang digunakan yaitu $S(0)=\frac{700}{1000}, C(0)=\frac{250}{1000}$, $I(0)=\frac{40}{1000}$, dan $R(0)=\frac{10}{1000}$, dengan total populasi $N=1000$. Adapun parameter-parameter yang digunakan sebagai berikut:

Tabel 1 Parameter yang Digunakan Untuk Simulasi Numerik

\begin{tabular}{|c|c|c|c|c|c|}
\hline \multirow[b]{2}{*}{ Parameter } & \multirow[b]{2}{*}{ Keterangan } & \multicolumn{4}{|c|}{ Nilai Parameter } \\
\hline & & $\left(\begin{array}{l}u_{1}=1 \\
u_{2}=1\end{array}\right)$ & $\left(\begin{array}{l}u_{1}=1 \\
u_{2}=0\end{array}\right)$ & $\left(\begin{array}{l}u_{1}=0 \\
u_{2}=1\end{array}\right)$ & $\left(\begin{array}{l}u_{1}=0 \\
u_{2}=0\end{array}\right)$ \\
\hline$\alpha$ & $\begin{array}{l}\text { Laju perkembangan infeksi } \\
\text { menjadi infeksi bergejala }\end{array}$ & 0.2 & 0.2 & 0.2 & 0.2 \\
\hline$\beta$ & Laju kontak efektif & 0.88 & 0.88 & 0.88 & 0.88 \\
\hline$\mu$ & Angka kematian alami & 0.01 & 0.01 & 0.01 & 0.01 \\
\hline$\delta$ & Angka kematian akibat penyakit & 0.1 & 0.1 & 0.1 & 0.1 \\
\hline$\omega$ & Angka kesembuhan alami & 0.2 & 0.2 & 0.2 & 0.2 \\
\hline$\theta$ & Angka hilangnya imunitas & 0.0839 & 0.0839 & 0.0839 & 0.0839 \\
\hline$\sigma$ & Efektifitas vaksinasi & 0.85 & 0.85 & 0.85 & 0.85 \\
\hline$\gamma$ & Efektifitas pengobatan & 0.9 & 0.9 & 0.9 & 0.9 \\
\hline $\mathfrak{R}_{0}$ & Angka reproduksi dasar & 0.07 & 0.54 & 0.8 & 6.04 \\
\hline
\end{tabular}

Dengan menggunakan parameter-parameter pada Tabel 1 diperoleh grafik sebagai berikut 


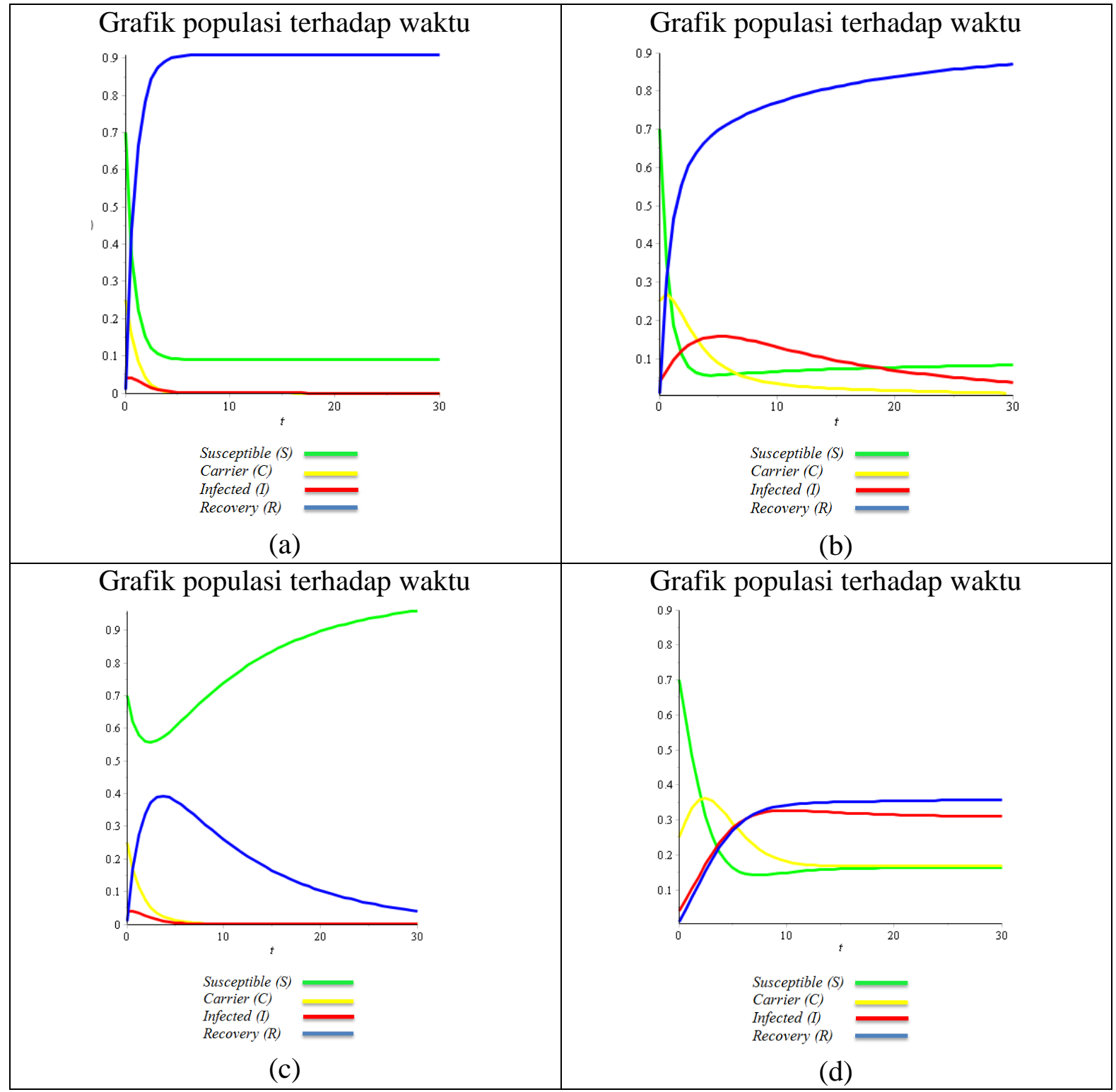

Gambar 1. Grafik Simulasi Penyebaran Penyakit Meningitis (a) $u_{1}=1, u_{2}=1, \mathfrak{R}_{0}=0.07$, (b) $u_{1}=1, u_{2}=0, \Re_{0}=0.54$, (c) $u_{1}=0, u_{2}=1, \Re_{0}=0.8$, (d) $u_{1}=0, u_{2}=0, \Re_{0}=6.04$

Dapat dilihat pada Tabel 1 bahwa apabila diberi perlakuan vaksinasi ataupun pengobatan, angka reproduksi dasar bernilai $\mathfrak{R}_{\mathbf{0}} \leq \mathbf{1}$. Apabila tidak diberikan perlakukan vaksinasi dan pengobatan, angka reproduksi dasar bernilai $\mathfrak{R}_{\mathbf{0}}>\mathbf{1}$. Artinya tidak adanya perlakuan vaksinasi dan pengobatan membuat penularan meningkat, sehingga individu terinfeksi terus bertambah. Hal tersebut dapat mengakibatkan terjadinya kondisi endemik. Adapun perubahan jumlah individu per 1000 populasi pada masing-masing sub-populasi dapat dilihat pada Gambar 1.

\section{PENUTUP}

Penyebaran penyakit meningitis dapat dimodelkan dalam bentuk sistem persamaan diferensial seperti pada Persamaan (2). Adapun titik-titik kesetimbangan yang diperoleh dari model tersebut yaitu titik kesetimbangan bebas penyakit $\left(E_{0}\right)$ dan titik kesetimbangan endemik $\left(E_{1}\right)$. Model tersebut akan stabil asimtotik global pada titik kesetimbangan bebas penyakit jika angka reproduksi dasar bernilai $\Re_{0} \leq 1$. Pada titik kesetimbangan endemik model akan stabil asimtotik global jika $\mu u_{1} \sigma>$ $\mu \Re_{0}\left(\mu+\theta+u_{1} \sigma\right)+(\mu+\theta)$ dan $\Re_{0}>1$. Apabila dilakukan vaksinasi atau pengobatan, maka 
jumlah individu pada sub-populasi terinfeksi akan berkurang nilainya hingga mencapai kurang dari 10 individu per 1000 populasi. Apabila tidak dilakukan vaksinasi dan pengobatan, jumlah individu pada sub-populasi terinfeksi akan mencapai lebih dari 10 individu per 1000 populasi.

\section{DAFTAR PUSTAKA}

[1] Vereen KJ. An SCIR Model of Meningococcal Meningitis. Virginia: Virginia Commonwealth University; 2008.

[2] Asamoah JKK, Nyabadza F, Seidu B, Chand M, Dutta H. Computational and Methematical Methods in Medicine: Hindawi. Mathematical Modelling of Bacterial MeningitisTransmission Dynamics with Control Measures. 2018.

[3] Blyuss KB. Springer International Publishing Switzerland. Mathematical Modelling of the Dynamics of Meningoococcal Meningitis in Afrika. 2016. 221-226

[4] Shuai Z, Driessche PVD. Society for Industrial and Applied Mathematics. Global Stability of Infectious Disease Models Using Lyapunov Functions. 2013; 73: 1513-1532.

[5] Luenberger DG. Introduction to Dynamic Systems Theory, Models, and Applications. Canada: John Wiley \& Sons; 1979.

[6] Li MY. An Introduction to Mathematical Modeling of Infectious Disease.Canada: Spinger International Publishing; 2018.

$\begin{array}{ll}\text { IRSYA AFIFAH } & \begin{array}{l}\text { : Jurusan Matematika FMIPA UNTAN, Pontianak, } \\ \text { afifahirsya @ gmail.com }\end{array} \\ \text { HELMI } & \begin{array}{l}\text { Jurusan Matematika FMIPA UNTAN, Pontianak, } \\ \text { helmi132205@yahoo.co.id } \\ \text { : Jurusan Matematika FMIPA UNTAN, Pontianak, } \\ \text { evi_noviani@ math.untan.ac.id }\end{array}\end{array}$

